Rakenteiden Mekaniikka (Journal of Structural Mechanics)

Vol. 54, No. 1, 2021, pp. 1-20

http://rakenteidenmekaniikka.journal.fi/index

https://doi.org/10.23998/rm.84590

(C) 2021 The Authors

Open access under license CC BY 4.0

\title{
3D simulations of deep mixed columns under road embankment
}

\author{
Ayman Abed ${ }^{1}$, Leena Korkiala-Tanttu, Juha Forsman and Kirsi Koivisto
}

Summary When column stabilisation is meant to function as a ground improvement under an embankment, the design cases to be considered consist of overall stability, compression resistance of the column heads, arching of the embankment on the columns and settlements. This paper focuses on the compression resistance of the columns. The proper geotechnical design of deep mixed (deep stabilised) columns under road embankment requires good estimation of the stressstrain behaviour of the columns and the surrounding soil under the embankment and traffic loading. Earlier Finnish design approaches relied on an even traffic load of $10 \mathrm{kN} / \mathrm{m}^{2}$ on the road surface. The dimensioning methods for column stabilised soil are also based on the idea of an even traffic load. Due to Eurocode recommendations a more realistic scenario is introduced, which remarkably increases the magnitude of the traffic loading. After deriving suitable material properties and stiffness parameters for static and dynamic traffic loading, three-dimensional finite element calculations are performed to achieve better understanding of the mechanical interaction between the embankment, columns and soil under the new loading configuration. Even though more investigations are needed before delivering a final statement, the calculations show that, for the considered case in this paper, the new loading scenario has no relevant consequences on the design compared to the earlier design approach.

Key words: soil stabilisation, finite-element modelling, dynamic loading.

Received: 20 August 2019. Accepted: 5 August 2020. Published online: 20 January 2021.

\section{Introduction}

Deep mixing or deep stabilisation is a widely used ground improvement method in Finland in areas of soft clay [10]. Especially the use of columns made with the dry mixing method has established its role in Nordic foundation engineering [30]. In column stabilisation, a mixing head is pushed and rotated though the soft subsoil into the desired depth. Then it is raised up by rotating while simultaneously adding binder material pneumatically into the soil [5]. After a curing time, typically from one to three months, 
the hardened columns and surrounding soft soil between the columns create an inhomogeneous soil mass, where in the long-term stresses concentrate mainly on the columns.

Finnish Transport Agency (FTA) has updated the guidelines for the design of deep mixing [7]. The implementation of the Eurocode approach with new traffic loads was the main drive behind updating the earlier guidelines from 2010 [9]. FTA substantially updated the traffic loads for roads in their guideline NCCI7 [8]. The loads presented in "Geotechnical Design, Application guidelines for Eurocode in Finnish FTA's guideline NCCI7" [8] are based on the measurements made on the Finnish road network during 2013 and 2014 [29]. Earlier, the design traffic load for roads [6, 9] was an evenly distributed $10 \mathrm{kN} / \mathrm{m}^{2}$. According to the new regulations the traffic load became an evenly distributed load of $9 \mathrm{kN} / \mathrm{m}^{2}$ with an additional distributed load of $31 \mathrm{kN} / \mathrm{m}^{2}$ at the area of $3 \mathrm{~m} \times 5 \mathrm{~m}$ on one lane. The location of this additional load can vary (Figure 1).

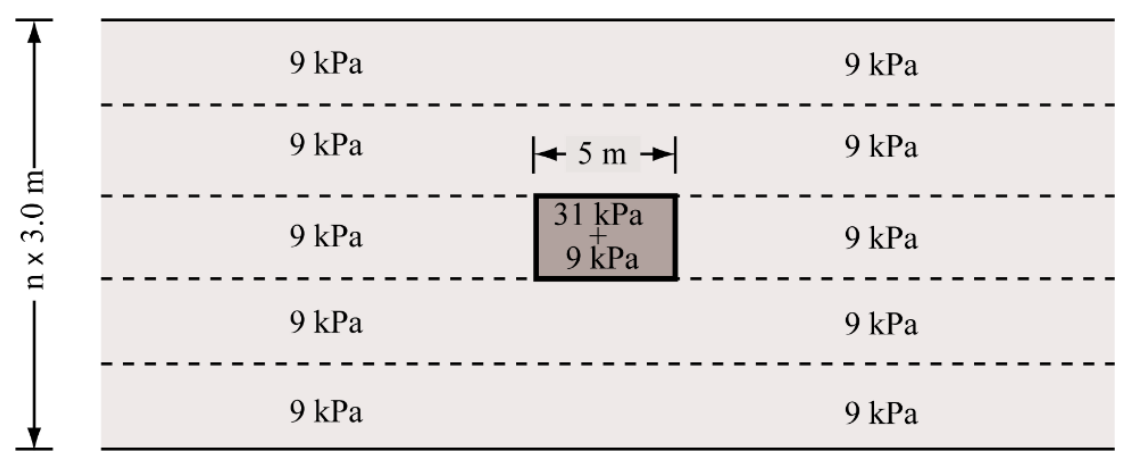

Figure 1. Top view of the traffic load for road design according to NCCI7 [8].

Broms and Boman [3] presented the design principles of elastic columns based on the concept of equal strain of columns and soil. The elastic column means that in the design the yield stress of columns, assumed to be $70 \%$ of the failure strength, is not exceeded. The design of the columns is based on the allowed load of the column. The design method applies a long-term modulus for the columns and the soft soil between columns [7, 9]. The earlier design guidelines adopted the analytical method of linear elasticity [23] to estimate the stress distribution between columns and the surrounding soil $[9,3]$. The 10 $\mathrm{kN} / \mathrm{m}^{2}$ even traffic loading was assumed not to be distributed in the embankment or in the dry crust layer.

In the case of an additional distributed loading of $31 \mathrm{kN} / \mathrm{m}^{2}$ (on an area of $3 \mathrm{~m} \times 5 \mathrm{~m}$ ) the load is assumed to be distributed in the embankment. The stress distribution in the embankment and subsoil layers was simulated for both the uniform loading of $10 \mathrm{kN} / \mathrm{m}^{2}$ and the updated traffic loading. The comparison showed a clear increase of the stress level for the $31 \mathrm{kPa}$ loading in the upper part of the column compared to the previously implemented loading of $10 \mathrm{kPa}$. This increase would directly affect the design, and the centre-to-centre (c/c) distance for the elastic columns would decrease (or the diameter of the columns or the binder amount would increase) leading to more expensive deep mixing for the embankment foundation. However, the existing deep mixed column structures have performed quite well, and during the last 40 years only in few cases have problems 
been reported in the existing column structures. In some of these cases, no dry crust layer has existed and the embankment has been thin, so the traffic load at the uppermost part of the column has exceeded the yield stress level.

Based on the simulations made during updating the guidelines, it was found that the new distributed traffic load and the earlier dimensioning method cannot be combined before more consideration is done. In the simulations, the old even traffic load of $10 \mathrm{kPa}$ was replaced by a new distributed load, which in analytical calculations gives somewhat overconservative results. To find a solution to this issue, versatile three-dimensional numerical simulations are done. The objective of this paper is to present and discuss the results of three-dimensional simulations of a road embankment over column-stabilised soil that is subjected to a traffic load configuration which meets the new design guidelines. Implicitly, the paper proposes a method to define the material parameters for similar loading scenarios. On the grounds of the numerical results, the paper delivers recommendations for improving the current design practice of such cases.

\section{Problem geometry}

Figure 2 illustrates the road cross section, its dimensions, columns and the subsoil in 3D space. The dimensions of the embankment correspond to a fairly conventional Finnish case of column stabilisation as a ground improvement method. The height of the embankment is 2 meters, the width 10 meters and the inclination of slopes 1:2. The subsoil has two layers: i) dry crust which is a thin, relatively strong partially saturated clay layer that lies directly over a soft saturated clay layer. In Finland the typical thickness of dry crust is 0.5 to 3 meters. The current study considers an average thickness of 1 meter. The current study considers an average thickness of 1 meter ii) soft clay of 10 meters. Below, there is a stiff soil layer (moraine). The soft clay has the typical properties for a coastal Finland clay. Two column spacings were chosen with the centre-to-centre (c/c) distances of $0.9 \mathrm{~m}$ and $1.3 \mathrm{~m}$, and a diameter of $600 \mathrm{~mm}$ for the columns. The columns were of two different types, soft and stiff. The diameter, c/c distance and the strength of the elastic columns were selected according to analytical calculations done following the guidelines of FTA (2010) [9] with the evenly distributed traffic load of $10 \mathrm{kN} / \mathrm{m}^{2}$.

The stress distributions were mainly analysed on the bottom of the dry crust and along the column in the middle of the road (see the red rectangle in Figure 2). This area is normally the most critical part of the column in the compression strength design. The columns were assumed to behave as an elastic material.

When the columns are elastic, the embankment load is distributed over the columns and subsoil in relation to their area-weighted stiffness. About $90-95 \%$ of the embankment load is typically distributed to the columns. 


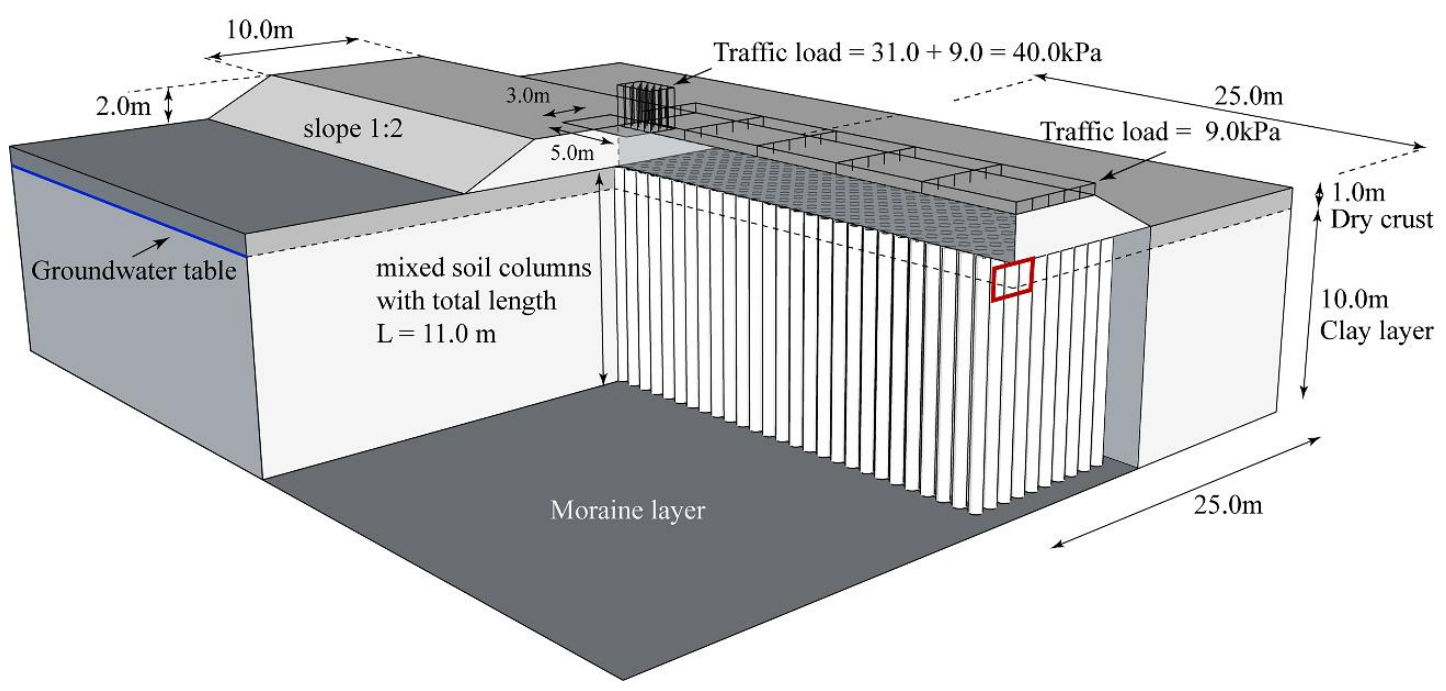

Figure 2. Problem geometry. Distance between the columns $(\mathrm{D}=600 \mathrm{~mm})$ is $\mathrm{c} / \mathrm{c}=0.9$ or $1.3 \mathrm{~m}$. The stress distributions were mainly analysed at the bottom of the dry crust and along the column in the middle of the road and subsoil - see the red rectangle.

\section{Parameters in different design situations}

The compression resistance of the columns should be analysed e.g. in the following two cases:

1. Final embankment and pavement structure + dynamic traffic load.

2. Final embankment and pavement structure + a static live load (e.g. truck parking area).

Case 1 is the most common, where the stress caused by the fast-acting (dynamic) traffic load is passed to the columns, to the granular structure of the soil between columns and to the generated excess pore pressure. Whereas, under the static load, the excess pore pressure has time to partly dissipate, and a greater portion of the load concentrates on the columns and the granular structure of the soil between columns than in the case of the dynamic load. This article mainly discusses case 1 , however the soil parameters are derived for both cases.

The previous design guidelines [9] used stiffness modulus $\mathrm{E}_{\mathrm{col}}$ for columns and drained state tangent modulus $M$ for soil. The modelling with dynamic traffic load, presented in this paper, uses initial undrained stiffness modulus $\mathrm{E}_{\mathrm{u}, \mathrm{col}}^{0}$ for columns and $\mathrm{E}_{\mathrm{u} \text {,soil }}^{0}$ for the soil between columns. To define the initial stress state equivalent to the embankment load, drained Young's modulus E' is used for the soil between columns and $\mathrm{E}_{\mathrm{col}}$ for columns. Only linear elastic material models are employed in the current FEM modelling.

It is worth mentioning that when modelling the structure with the static load, drained elastic modulus $\mathrm{E}_{0}$ was employed for the soil between columns. Even though the modelling of this case is not presented here but the needed parameters are provided in the following section. 


\section{Material parameters}

Embankment: Finnish Road Administration [6] has defined design parameters for the embankment. In the current study, the commonly used value for the total unit weight 20 $\mathrm{kN} / \mathrm{m}^{3}$ was chosen (crushed aggregate). The Poisson's ratio usually applied to crushed aggregate is 0.2 [31]. Kolisoja [15] has defined Young's modulus E' for different unbound pavement materials based on the results from static large-scale laboratory tests. The static secant modulus for natural and crushed rock materials was found to vary between 236$515 \mathrm{MPa}$. The selected value for this study was $300 \mathrm{MPa}$.

Dry crust: Ringesten [24] has collected material parameters for weathered dry crusts around Sweden. According to his studies, the bulk density varies between 16 and 19 $\mathrm{kN} / \mathrm{m}^{3}$. According to Köylijärvi [16] the effective unit weight in the lower part of the dry crust was $17.2 \mathrm{kN} / \mathrm{m}^{3}$ for Helsinki region. Vinter [31] suggested a value of $18 \mathrm{kN} / \mathrm{m}^{3}$, which has been chosen for the presented modelling. For the drained stiffness modulus E', Vinter [31] has applied a value of $50 \mathrm{MPa}$ and Köylijärvi [16] a value of $25 \mathrm{MPa}$. After the preliminary modelling it became clear that the value of $50 \mathrm{MPa}$ was a bit too high and the value of $25 \mathrm{MPa}$ too low, so after some deliberation the selected value was changed to $39 \mathrm{MPa}$.

Clay: For Perniö clay, which represents the common fat clay of Southern Finland, Löfman [19] showed that the mean total unit weight for 142 samples varied between 14.2 and $15.1 \mathrm{kN} / \mathrm{m}^{3}$. Ronkainen [25] analysed a database of 104 samples, where the yielded mean total value was $15.6 \mathrm{kN} / \mathrm{m}^{3}$. Accordingly, the chosen value for total unit weight was $15 \mathrm{kN} / \mathrm{m}^{3}$ and effective unit weight $5 \mathrm{kN} / \mathrm{m}^{3}$. The plasticity index $\mathrm{I}_{\mathrm{p}}=\mathrm{w}_{\mathrm{l}}-\mathrm{w}_{\mathrm{p}}$ (liquid limit - plastic limit) of Finnish clays is in average ranges between 25\% to 35\% [25]. Finnish clays are often lightly over consolidated with OCR $=1.2 \ldots 1.5$ [19]. Poisson's ratio $v$ ' for soft clay was selected to be 0.33 [33] and the drained modulus E' is linked to the undrained modulus $E_{\mathrm{u}}$ and undrained Poisson's ratio $v_{\mathrm{u}}(0,5)$ defined later, according to Equation 1.

$$
\mathrm{E}^{\prime}=\mathrm{E}_{\mathrm{u}} \cdot \frac{\left(v^{\prime}+1\right)}{\left(v_{\mathrm{u}}+1\right)}
$$

There exists relatively little data for undrained Young's modulus for Finnish clays, therefore a chart by Kulhawy and Mayne [17] was applied. The undrained modulus is commonly normalized with the undrained shear strength $\left(s_{u}\right)$ from the same triaxial test. The chart by Kulhawy and Mayne [17] gives $\mathrm{E}_{\mathrm{u}}$ values between 7.5 and $19 \mathrm{MPa}$ where $\mathrm{s}_{\mathrm{u}}$ for the soft clay is around $12.5 \mathrm{kPa}$. An average value of $15 \mathrm{MPa}$ for static undrained modulus is adopted, yielding $\mathrm{E}^{\prime}=13.3 \mathrm{MPa}$.

Stabilised clay: According to Hassan [11] the bulk density of stabilised clay increases for example by $50-60 \mathrm{~kg} / \mathrm{m}^{3}$ when the binder amount increases from 50 to $150 \mathrm{~kg} / \mathrm{m}^{3}$. For soft columns, the same effective unit weight as for clay $\left(\gamma^{\prime}=5 \mathrm{kN} / \mathrm{m}^{3}\right)$ was employed, because the amount of the binder is low. However, for stiff columns $\gamma^{\prime}$ was increased to 6 $\mathrm{kN} / \mathrm{m}^{3}$.

The reported values by Navin [21] for the effective Poisson's ratio $v^{\prime}$ of stabilised material vary between 0.25 and 0.5 . Vogler [32] presented modelling calculations of 
stabilised soil with $v^{\prime}=0.35$ for the columns. An average value of 0.33 was adopted for the current modelling. Determining the stiffness of stabilised soil is challenging and therefore it is common to use empirical correlations between the undrained shear strength of stabilised soil $\mathrm{s}_{\mathrm{u}, \mathrm{col}}$ and the related stiffness. Timoney [28] collected a list of these equations to estimate the stiffness $\mathrm{E}_{\mathrm{col}}$ both from laboratory and field tests. Many of the equations are linear and, for the most part, quite similar to each other. One of the more common ones is Equation 2, which was also used in the old Finnish guide book [6].

$$
\mathrm{E}_{\mathrm{col}}=100 \sim 200 \cdot \mathrm{s}_{\mathrm{u}, \mathrm{col}}
$$

where $\mathrm{s}_{\mathrm{u}, \mathrm{col}}$ is estimated in $[\mathrm{kPa}]$.

According to Swedish Road Administration [27] the stiffness modulus for columns $\mathrm{E}_{\mathrm{col}}$ can be derived from Equation 3, where $0.7 \times \mathrm{s}_{\mathrm{u}, \mathrm{col}}$ represents the value of the shear yielding strength for the stabilised soil of columns. In both the new and the former Finnish guidelines [7, 9], the column stiffness is derived based on Equation 4.

$$
\begin{aligned}
& E_{\text {col }}=13\left(0.7 s_{u, c o l}\right)^{1.6} \\
& E_{c o l}=20\left(0.7 s_{u, c o l}\right)^{1.6}
\end{aligned}
$$

To make the design cases as realistic as possible, it was assumed that the "soft" columns and the "stiff" columns have the shear strengths of $70 \mathrm{kPa}$ and $150 \mathrm{kPa}$, respectively. Consequently, based on Equations 2 and 4 taken from Finnish handbooks, the nominal values of column stiffness are 7-14 MPa (Eq. 2) or $10 \mathrm{MPa}$ (Eq. 4) for the "soft" columns and 15-30 or $34 \mathrm{MPa}$ for the "stiff" columns. Table 1 shows the literature values and the selected material parameters. The stiffness parameters in this table are used for modelling the case of static traffic loading (not presented in this paper).

Table 1. Material parameters. Literature values / selected values.

\begin{tabular}{lccc}
\hline Material & $\begin{array}{c}\text { Unit weight } \gamma^{\prime} \\
{\left[\mathrm{kN} / \mathrm{m}^{3}\right]}\end{array}$ & $\begin{array}{c}\text { Drained Poisson's } \\
\text { ratio } v^{\prime}[-]\end{array}$ & $\begin{array}{c}\text { Drained Young's } \\
\text { modulus E' [MPa] }\end{array}$ \\
\hline Embankment & $20 / 20$ & $0.21 / 0.2$ & $236-515^{2} / 300$ \\
Dry crust & $18^{1} / 18$ & $0.31 / 0.3$ & $25^{9}-50^{2} / 39$ \\
Clay, soft & $14.2-15.1^{3} / 15$ & $0.33^{4} / 0.33$ & $6.6-17^{5} / 13.3^{5}$ \\
Column, soft & $15^{6} / 15$ & $0.35^{7} / 0.33$ & $7-14 / 14^{8}$ \\
Column, stiff & $16^{6} / 16$ & $0.35^{7} / 0.33$ & $15-34 / 30^{8}$ \\
\hline
\end{tabular}

${ }^{1}[31]^{2}[15]^{3}[19]{ }^{4}[33]^{5}[17]^{6}[11]{ }^{7}[32]^{8}[6,7]^{9}[16]$

\section{Stiffness parameters for dynamic traffic load}

Due to the dynamic nature of the traffic loading, resulting strains are likely to be small. Therefore, small strain stiffness parameters were selected for the modelling of traffic loading (case 1).

Clay: Small strain stiffness can be estimated with the help of the initial shear modulus. The modulus E relates to the shear modulus $G$ according to Equation 5, which is based on the theory of elasticity. Robertson [26] suggests a Poisson's ratio value of 0.2 for 
drained soil behaviour at small strains, which means, based on Equation 5 that the relationship between the initial shear modulus $\mathrm{G}_{0}$ and initial elastic modulus $\mathrm{E}_{\text {soil }}^{0}$ can be estimated with Equation $6 \mathrm{a}$ in drained and $6 \mathrm{~b}$ in undrained condition.

$$
\begin{gathered}
\mathrm{E}=2 \mathrm{G}(v+1) \\
\mathrm{E}_{\text {soil }}^{0} \approx 2.4 \mathrm{G}_{0}, \text { when } v=0.2 \\
\mathrm{E}_{\mathrm{u}, \text { soil }}^{\mathrm{o}} \approx 3 \mathrm{G}_{0}, \text { when } v=0.5
\end{gathered}
$$

Mäenpää [20] presented several different ways to estimate the initial shear modulus $\mathrm{G}_{0}$ from literature. Most of the existing estimation methods are given in terms of shear strength, over-consolidation degree and plasticity index. For plastic clays the initial shear modulus can be estimated based on Equation 7, proposed by Larsson and Mulabdic' [18].

$$
\mathrm{G}_{\mathrm{o}}=\left(\frac{\mathrm{A}}{\mathrm{I}_{\mathrm{p}}}+\mathrm{B}\right) \mathrm{s}_{\mathrm{u}, \text { soil }}
$$

They suggest regression values $\mathrm{A}=208$ and $\mathrm{B}=250$, which are constants that provide good fit for Scandinavian clays. As mentioned earlier, the plasticity index $\mathrm{I}_{\mathrm{p}}$ is usually around 0.35 for Finnish clays. A typical shear strength $\mathrm{s}_{\mathrm{u}, \mathrm{soil}}$ of clay under the dry crust is $10 \mathrm{kPa}$ at Finnish coastal areas. With these values, Equation 7 yields $\mathrm{G}_{0}=8.44 \mathrm{MPa}$. Employing Equation 6a the initial effective stiffness modulus $\mathrm{E}_{\text {soil }}^{0}=20.3 \mathrm{MPa}$ for a typical Finnish clay at the areas where column stabilisation is used. Equation $6 \mathrm{~b}$ can also be used to estimate the initial undrained stiffness modulus $\mathrm{E}_{\mathrm{u} \text {,soil }}^{0}$ by using the undrained Poisson's ratio of $v_{\mathrm{u}}=0.5$ and initial shear modulus of $\mathrm{G}_{0}=8.44 \mathrm{MPa}$, which gives $\mathrm{E}_{\mathrm{u} \text {,soil }}^{0}$ $=25.3 \mathrm{MPa}$.

Experimentally, the initial shear modulus can be determined from bender element test or seismic CPTU soundings. Mäenpää [20] did seismic CPTU soundings for four different, well-defined Finnish clay deposits and gave the following formula (Eq. 8).

$$
\mathrm{G}_{0}=900 \cdot \mathrm{s}_{\mathrm{u}, \text { soil }}
$$

Upon substituting with $\mathrm{s}_{\mathrm{u}, \mathrm{soil}}=10 \mathrm{kPa}$ in the above equation, a value of $\mathrm{G}_{0}=9.0 \mathrm{MPa}$ was derived, confirming the adopted value of $\mathrm{G}_{0}=8.44 \mathrm{MPa}$ for the analyses.

Stabilised clay: Chan [4] studied the initial shear modulus of stabilised kaolin samples. He proposed both linear and second-degree polynomial correlations between undrained shear strength $s_{u}$ and initial shear modulus $G_{0}$ for three different types of clay, one artificial (Speswhite kaolin) and two naturally occurring clays (Malaysian and Swedish clays). The clays were stabilised in the laboratory. The second-degree polynomial correlations worked properly only in the range of stresses equal to that of the original samples, but the linear correlations (Eqs. 9, 10 and 11) can be extrapolated to different stress ranges.

Speswhite kaolin:

$$
\mathrm{s}_{\mathrm{u}, \mathrm{col}}=0.644 \cdot 10^{-3} \cdot \mathrm{G}_{0} \rightarrow \mathrm{G}_{0}=1553 \cdot \mathrm{s}_{\mathrm{u}, \mathrm{col}}
$$


Malaysian clay:

Swedish clay:

$$
\mathrm{s}_{\mathrm{u}, \mathrm{col}}=1.473 \cdot 10^{-3} \cdot \mathrm{G}_{0} \rightarrow \mathrm{G}_{0}=679 \cdot \mathrm{s}_{\mathrm{u}, \mathrm{col}}
$$

$$
\mathrm{s}_{\mathrm{u}, \mathrm{col}}=1.105 \cdot 10^{-3} \cdot \mathrm{G}_{0} \rightarrow \mathrm{G}_{0}=905 \cdot \mathrm{s}_{\mathrm{u}, \mathrm{col}}
$$

Figure 3 shows the shear modulus / shear strength correlations from column samples of two Finnish test sites, one from the town of Kouvola [14] and the other from Vantaa [12]. The shear moduli of the test samples have been determined either with bender element or resonant column tests, and the shear strength has been derived from the quality control soundings of the columns at the test site.

In addition, Figure 3 presents the shear modulus / shear strength correlations used in the 2D FEM modelling done for the Kouvola test site [13]. The correlations by Chan [4] discussed above are also presented in Figure 3. Of the discussed correlations, the linear correlation given by Chan [4] for Malaysian clay (Eq. 10) fits best to the studied samples from Kouvola and Vantaa.

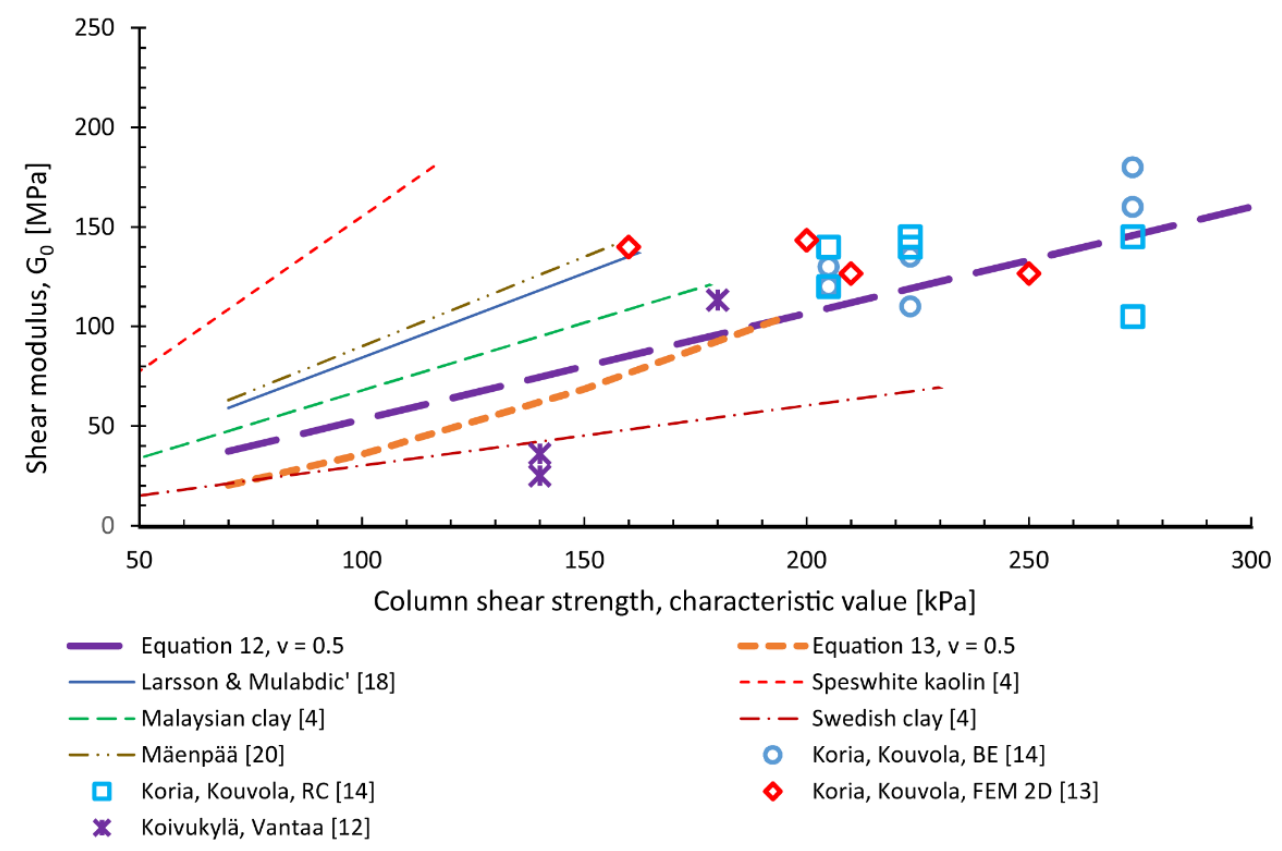

Figure 3. Correlations between small strain shear modulus $\mathrm{G}_{0}$ and shear strength $\mathrm{s}_{\mathrm{u}, \mathrm{col}}$ of stabilisation columns from different studies and from two test sites in Finland. (BE $=$ Bender element test, $\mathrm{RC}=$ Resonant column test).

To find a better approximation to the samples, equations 12 and 13 were created for the initial elastic modulus. Equation 12 was a linear fit, whereas Equation 13 was adapted based on Equation 4. Equation 13 has also been suggested as the one to be applied for small strain elastic modulus by the new Finnish guidelines [7]. Figure 3 shows the graphs of equations 12 and 13 together with the column sample correlations they were fitted to 


$$
\begin{gathered}
\mathrm{E}_{\mathrm{col}}=1600 \mathrm{~s}_{\mathrm{u}, \mathrm{col}} \\
\mathrm{E}_{\mathrm{col}}=120\left(0.7 \mathrm{~s}_{\mathrm{u}, \mathrm{col}}\right)^{1.6}
\end{gathered}
$$

Equation 13 is employed to estimate the initial elastic modulus for the stabilised column assuming an undrained shear strength of $70 \mathrm{kPa}$ and $150 \mathrm{kPa}$. For $\mathrm{s}_{\mathrm{u}, \mathrm{col}}=70 \mathrm{kPa}$ the initial elastic modulus varies from 47.5 to $109 \mathrm{MPa}$, whereas for $\mathrm{s}_{\mathrm{u}, \mathrm{col}}=150 \mathrm{kPa}$ it falls in the range of 102 to $233 \mathrm{MPa}$. Table 2 lists the adopted small strain stiffness parameters for clay and stabilised columns.

Table 2. Analysed cases and material parameters for a rapid traffic load for soft clay and stabilised columns (equations 12 and $5 \mathrm{~b}$ are used in the table columns 3 and 4 ).

\begin{tabular}{cccccc}
\hline $\begin{array}{l}\text { Case } \\
\text { No. }\end{array}$ & $\begin{array}{l}\text { c/c distance } \\
{[\mathrm{m}]}\end{array}$ & $\begin{array}{l}\text { Undrained shear } \\
\text { strength of column } \\
\text { su,col }[\mathrm{kPa}]\end{array}$ & $\begin{array}{l}\text { Undrained } \\
\text { stiffness of } \\
\text { column } \mathrm{E}_{\mathrm{col}} \\
{[\mathrm{MPa}]}\end{array}$ & $\begin{array}{l}\text { Undrained stiffness } \\
\text { of clay } \\
\mathrm{E}_{\text {soil }}[\mathrm{MPa}]\end{array}$ & $\begin{array}{l}\text { Ratio } \\
\mathrm{E}_{\text {col }} / \mathrm{E}_{\text {soil }}\end{array}$ \\
\hline $\mathbf{1}$ & $\mathbf{0 . 9}$ & $\mathbf{7 0}$ & $\mathbf{6 1}$ & $\mathbf{2 5 . 3}$ & \\
2 & 0.9 & 100 & 107 & 25.3 & $\mathbf{2 . 4}$ \\
3 & 0.9 & 150 & 206 & 25.3 & 4.2 \\
4 & 0.9 & 225 & 393 & 25.3 & 15.5 \\
7 & 1.3 & 70 & 61 & 25.3 & 2.4 \\
8 & 1.3 & 100 & 107 & 25.3 & 4.2 \\
$\mathbf{9}$ & $\mathbf{1 . 3}$ & $\mathbf{1 5 0}$ & $\mathbf{2 0 6}$ & $\mathbf{2 5 . 3}$ & $\mathbf{8 . 1}$ \\
10 & 1.3 & 225 & 393 & 25.3 & 15.5 \\
\hline
\end{tabular}

\section{D modelling}

\section{Finite element model}

The 3D finite element calculations were performed using PLAXIS 3D [22]. Figure 4 illustrates the problem geometry, dimensions and finite element mesh (for more details about the dimensions, see Figure 2). Due to symmetry, only a quarter of the problem is modelled. The example shown in Figure 4 represents the case of $\mathrm{c} / \mathrm{c}=0.9 \mathrm{~m}$. The finite element mesh consists of about 630000 ten-noded tetrahedron elements with four stress integration (Gauss) points per element. 


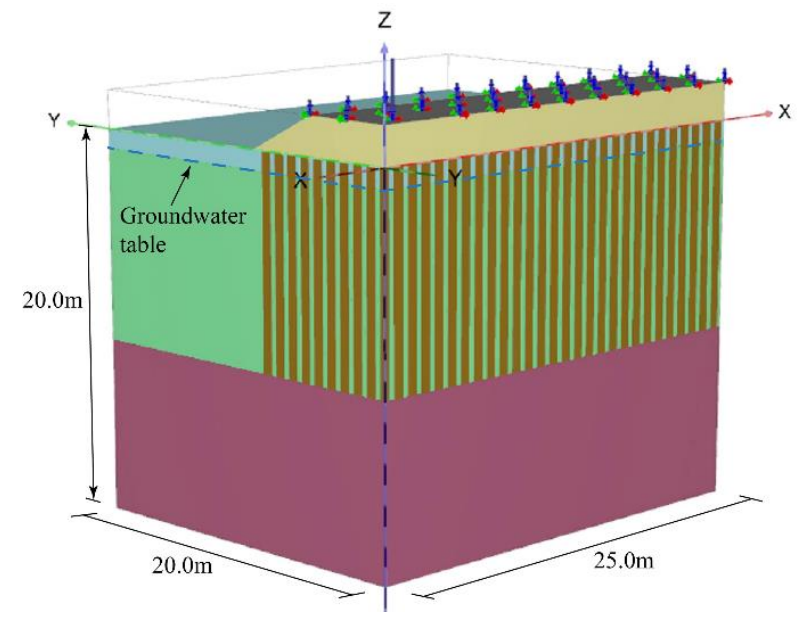

(a)

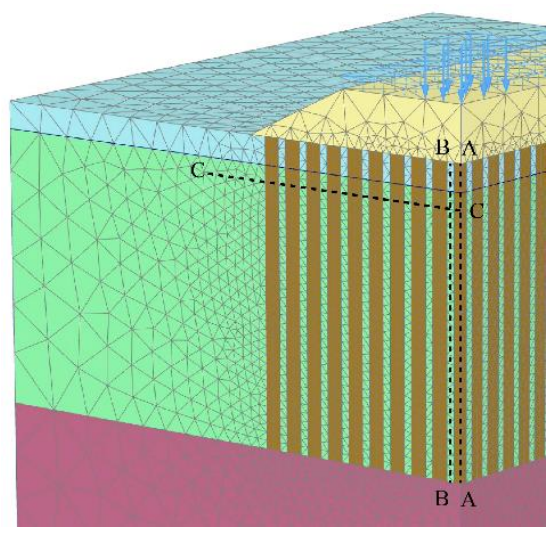

(b)

Figure 4. The employed geometry and dimensions. (a) model geometry with soil profile and loadings as presented in Figure 2. (b) part of the finite element mesh with the location of result sections: A-A at the centre of the middle column; B-B through the adjacent soil in the middle of the distance $\mathrm{c} / \mathrm{c} ; \mathrm{C}-\mathrm{C}$ is horizontal section at depth $1.5 \mathrm{~m}$.

\section{Material constitutive model and calculation phases}

Linear elastic material model was employed to simulate the response of all objects involved in the problem. Both the clay layer and column material were assumed to be in undrained conditions due to their very low permeability and rapid loading. The embankment body was assumed to be drained in all the calculation phases (high permeability). The following phases were adopted in the numerical simulation:

1. Initial phase: for generation of initial stresses ( $\mathrm{K}_{0}$ procedure).

2. Column installation phase: the initial soil material in the column cylinders is replaced by a material representing the desired column stiffness and properties.

3. Embankment construction phase: the embankment body is activated at this stage.

4. Consolidation phase: consolidation analysis is run to dissipate all the excess pore pressure that developed in the previous phases. The target is to reach zero excess pore water pressure before the traffic load is applied.

5. Traffic loading phase: undrained phase with the application of $9+31 \mathrm{kPa}$ traffic loading as in Figures 1 and 2.

The main goal was to study the increment in stresses in the critical column and in the adjacent soil due to the sudden application of traffic loading. This was assessed by subtracting the total displacements, stresses and strain results in phase 4 from the corresponding values at the end of phase 5 . The calculations were repeated for varying c/c-distances and stiffness ratios. Table 2 summarizes the performed simulations. Due to the similarity in the general behaviours, only the results from two cases with $\mathrm{c} / \mathrm{c}=0.9 \mathrm{~m}$ and $\mathrm{c} / \mathrm{c}=1.3 \mathrm{~m}$ are presented here in Figures 5-8. The full results are reported by Abed et al. $[1,2]$ and they are available upon request. However, the total outcome of the calculations is presented in the discussion and conclusion sections. 


\section{Calculation results}

Figure 5 presents the total displacements at the end of the calculations. This figure serves as a reference for the general response of the numerical model and adequacy of the position of the boundary conditions. It also shows that the model behaves qualitatively as expected and that the problem boundaries were correctly decided and were far enough to avoid any disturbance to the solution domain.

Figure 6 shows results along the section C-C at the depth of $-1.5 \mathrm{~m}$ and Figure 7 along sections A-A and B-B along the critical column and the adjacent soil. Respectively the case of $\mathrm{c} / \mathrm{c}=0.9 \mathrm{~m}$ and stiffness ratio of $\mathrm{E}_{\mathrm{col}} / \mathrm{E}_{\mathrm{soil}}=2.4$ is presented in the a-figures and the case of $\mathrm{c} / \mathrm{c}=1.3 \mathrm{~m}$ and stiffness ratio of $\mathrm{E}_{\mathrm{col}} / \mathrm{E}_{\mathrm{soil}}=8.1$ in the b-figures.

Figure 8 illustrates some characteristic output of the calculations. These results are for the case of $\mathrm{c} / \mathrm{c}=1.3 \mathrm{~m}$ and stiffness ratio of $\mathrm{E}_{\mathrm{col}} / \mathrm{E}_{\mathrm{soil}}=2.4$.

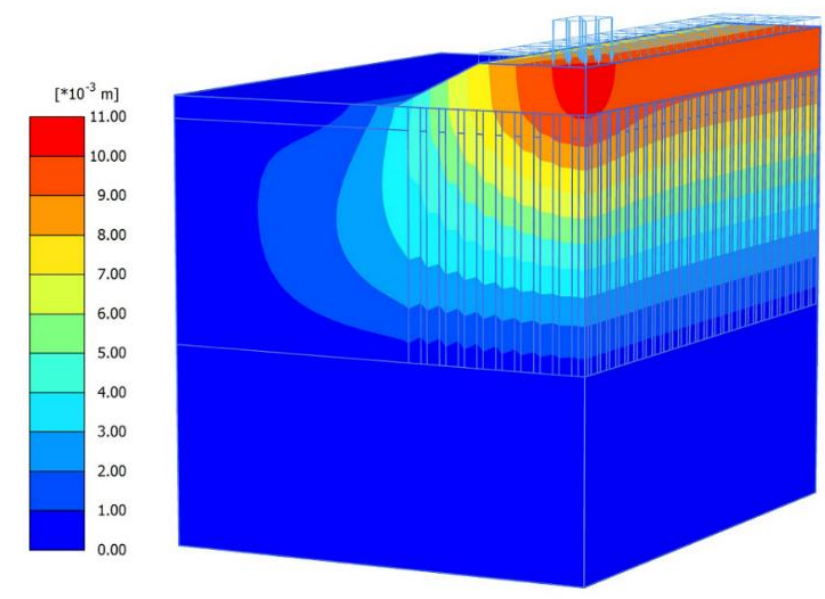

Figure 5. Model response: total displacement at the end of analysis 
a) $\mathrm{c} / \mathrm{c}=0.9 \mathrm{~m}+\mathrm{E}_{\mathrm{col}} / \mathrm{E}_{\mathrm{soil}}=2.4$

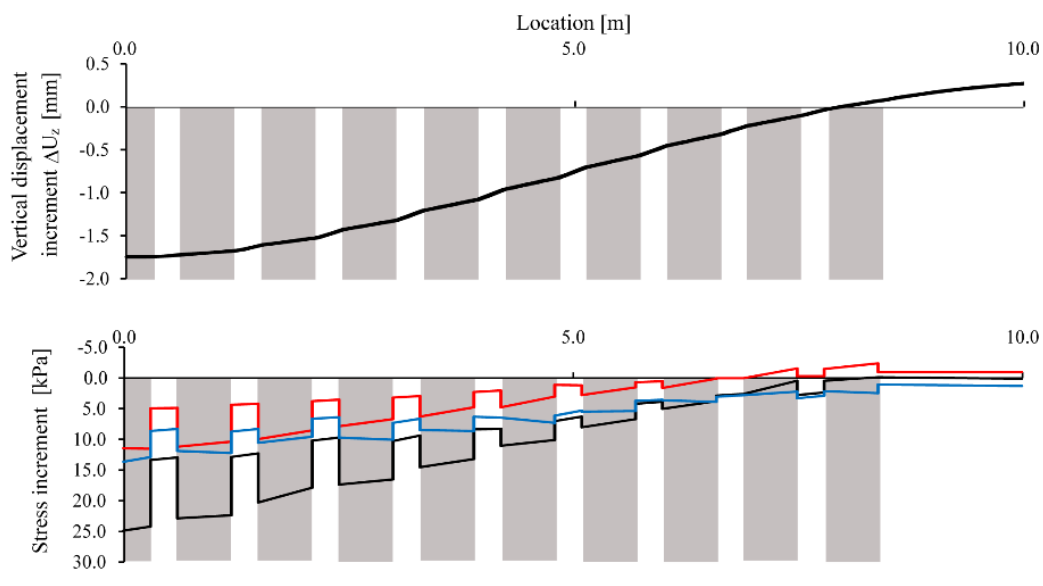

b) $\mathrm{c} / \mathrm{c}=1.3 \mathrm{~m}+\mathrm{E}_{\mathrm{col}} / \mathrm{E}_{\text {soil }}=8.1$
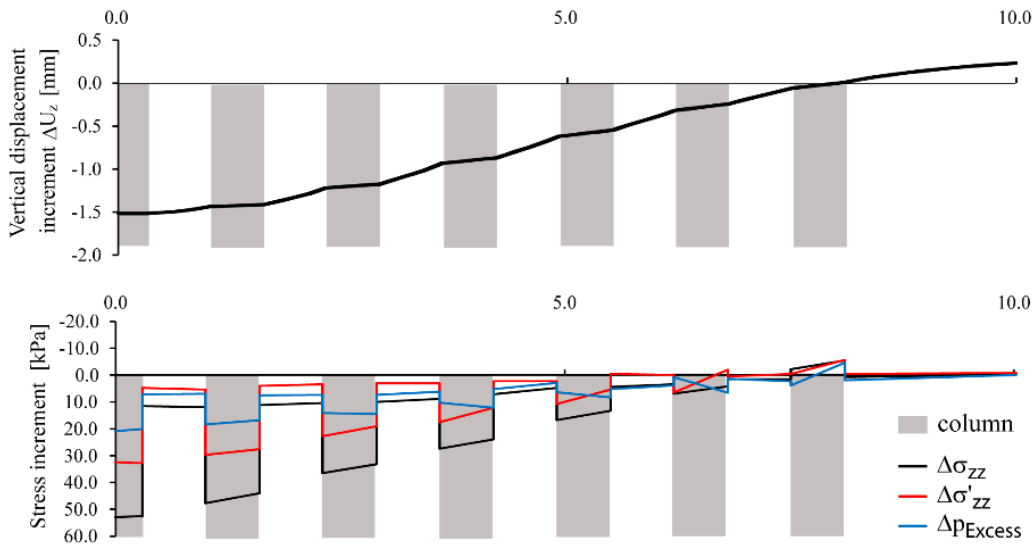

Figure 6. Calculation results, vertical displacement increment and vertical stress increment at the section C-C. Level $0 \mathrm{~m}$ is the bottom of the embankment. (a) $\mathrm{c} / \mathrm{c}=0.9 \mathrm{~m}+\mathrm{E}_{\mathrm{col}} / \mathrm{E}_{\mathrm{soil}}=2.4$ and (b) $c / c=1.3 \mathrm{~m}+\mathrm{E}_{\mathrm{col}} / \mathrm{E}_{\mathrm{soil}}=8.1$. Legends: total stress increment $\left(\Delta \sigma_{\mathrm{zz}}\right)$, effective stress increment $\left(\Delta \sigma_{\mathrm{zz}}{ }^{\prime}\right)$ and excess pore pressure increment $\left(\Delta \mathrm{p}_{\text {Excess }}\right)$. 
a) $\mathrm{c} / \mathrm{c}=0.9 \mathrm{~m}+\mathrm{E}_{\mathrm{col}} / \mathrm{E}_{\mathrm{soil}}=2.4$
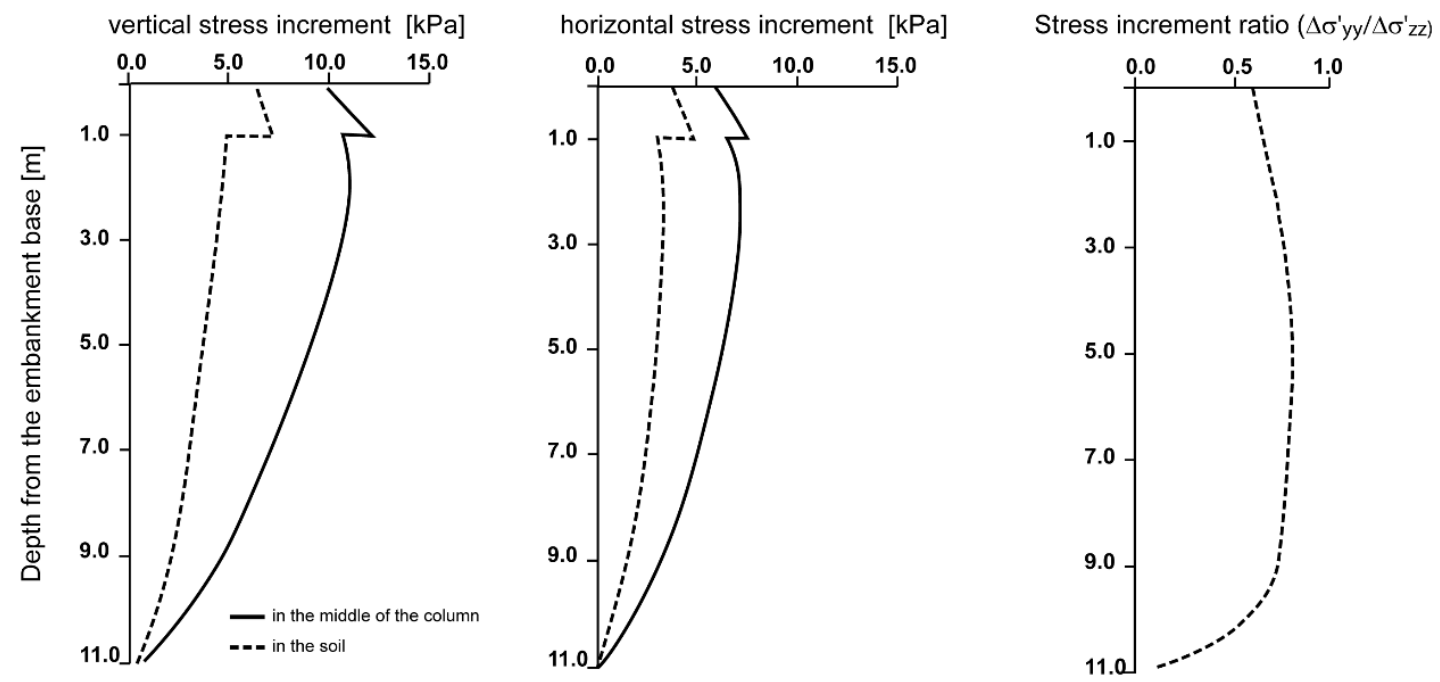

b) $\mathrm{c} / \mathrm{c}=1.3 \mathrm{~m}+\mathrm{E}_{\mathrm{col}} / \mathrm{E}_{\text {Soil }}=8.1$
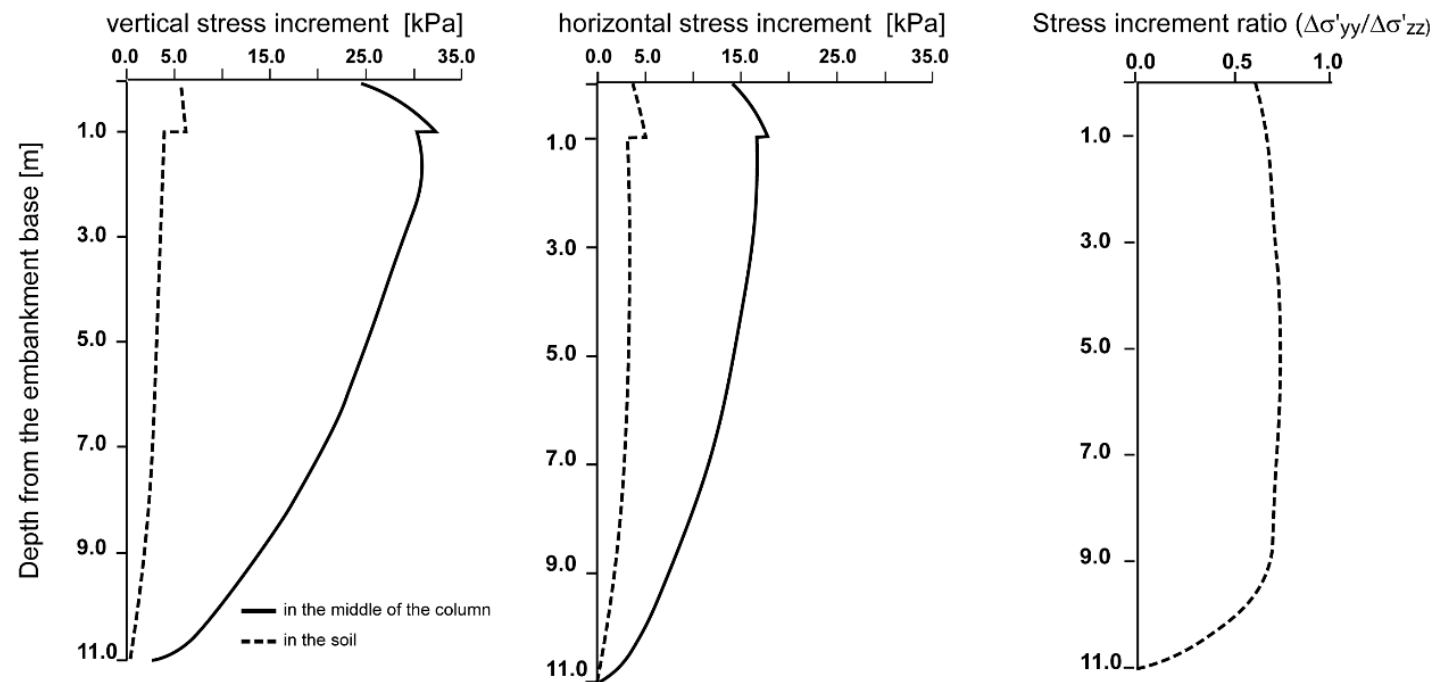

Figure 7. Calculation results, effective stress increment in the z-direction, y-direction and ratio between horizontal (y) and vertical (z) effective stress increments at sections A-A and B-B along the critical column and the adjacent soil, respectively. Level $0 \mathrm{~m}$ is the bottom of the embankment. (a) $\mathrm{c} / \mathrm{c}=0.9 \mathrm{~m}+\mathrm{E}_{\mathrm{col}} / \mathrm{E}_{\mathrm{soil}}=2.4$. (b) $\mathrm{c} / \mathrm{c}=1.3 \mathrm{~m}+\mathrm{E}_{\mathrm{col}} / \mathrm{E}_{\mathrm{soil}}=8.1$. 


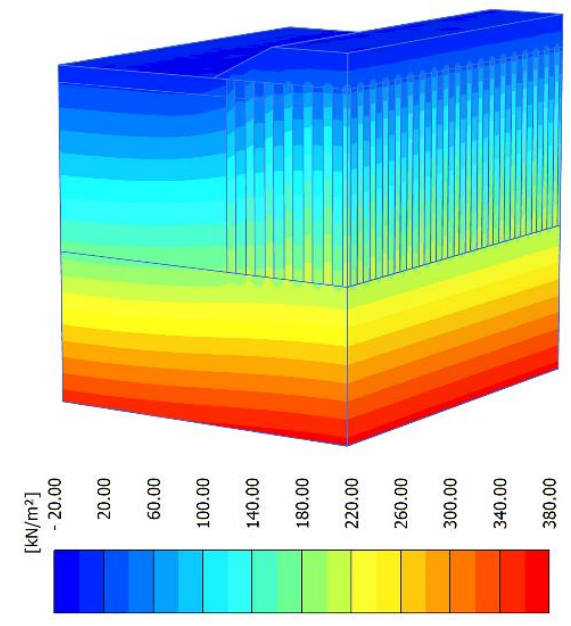

(a)

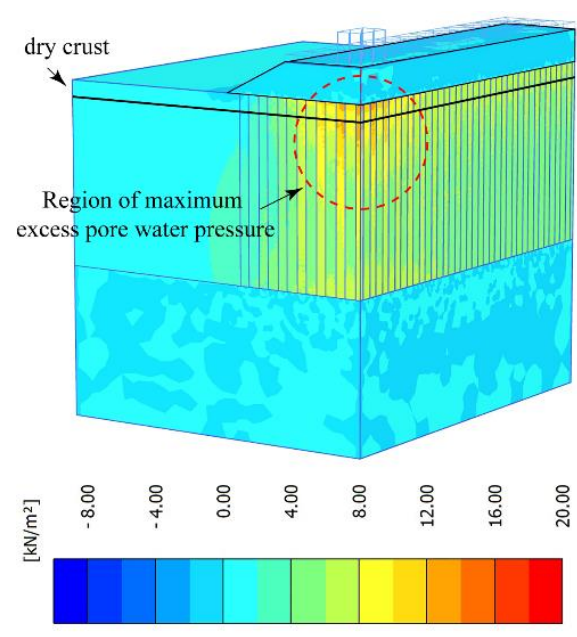

(b)

Figure 8. Example of the typical calculation output: (a) total vertical stress before traffic loading; and (b) excess pore water pressure after traffic loading $(\max \approx 20 \mathrm{kPa})$.

\section{Discussion}

Figure 9 illustrates the results of the eight calculations listed in Table 2. The vertical axis shows the depth from the road surface and the horizontal axis the calculated averaged vertical total stress increments due to traffic load. The numbers represent weighted values (with respect to the area of $\mathrm{c} / \mathrm{c}$ by c/c supported by one column) from each stress increment carried by the column and by the soil. The averaged vertical total stress increment due to traffic load is expressed by:

$$
\Delta \sigma_{\mathrm{z}_{\text {average }}}=\frac{\Delta \sigma_{\mathrm{z}_{\text {col }}} \times \mathrm{A}_{\text {col }}+\Delta \sigma_{\mathrm{z}_{\text {soil }}} \times A_{\text {soil }}}{A_{\text {col }}+A_{\text {soil }}}
$$

In Equation 14, $\mathrm{A}_{\mathrm{col}}$ and $\mathrm{A}_{\text {soil }}$ are the horizontal cross-section areas of the column and soil, respectively. The symbol $\Delta \sigma_{z \text {,average }}$ stands for the average value of vertical stress increment.

Figure 10 presents values of averaged vertical total stress increment due to traffic load compared to the results calculated with the Boussinesq and 2:1 -stress distribution theories. It appears that conclusive differences exist between the results from the Boussinesq, the 2:1 stress distribution and the results from 3D FEM calculated values.

$$
\begin{gathered}
\frac{\Delta \sigma_{\mathrm{z}, \text { average }}-\Delta \sigma_{\mathrm{z}, \text { Boussinesq }}}{\Delta \sigma_{\mathrm{z}, \text { Boussinesq }}} \cdot 100[\%] \\
\frac{\Delta \sigma_{\mathrm{z}, \text { average }}-\Delta \sigma_{\mathrm{z}, 2: 1}}{\Delta \sigma_{\mathrm{z}, 2: 1}} \cdot 100[\%]
\end{gathered}
$$




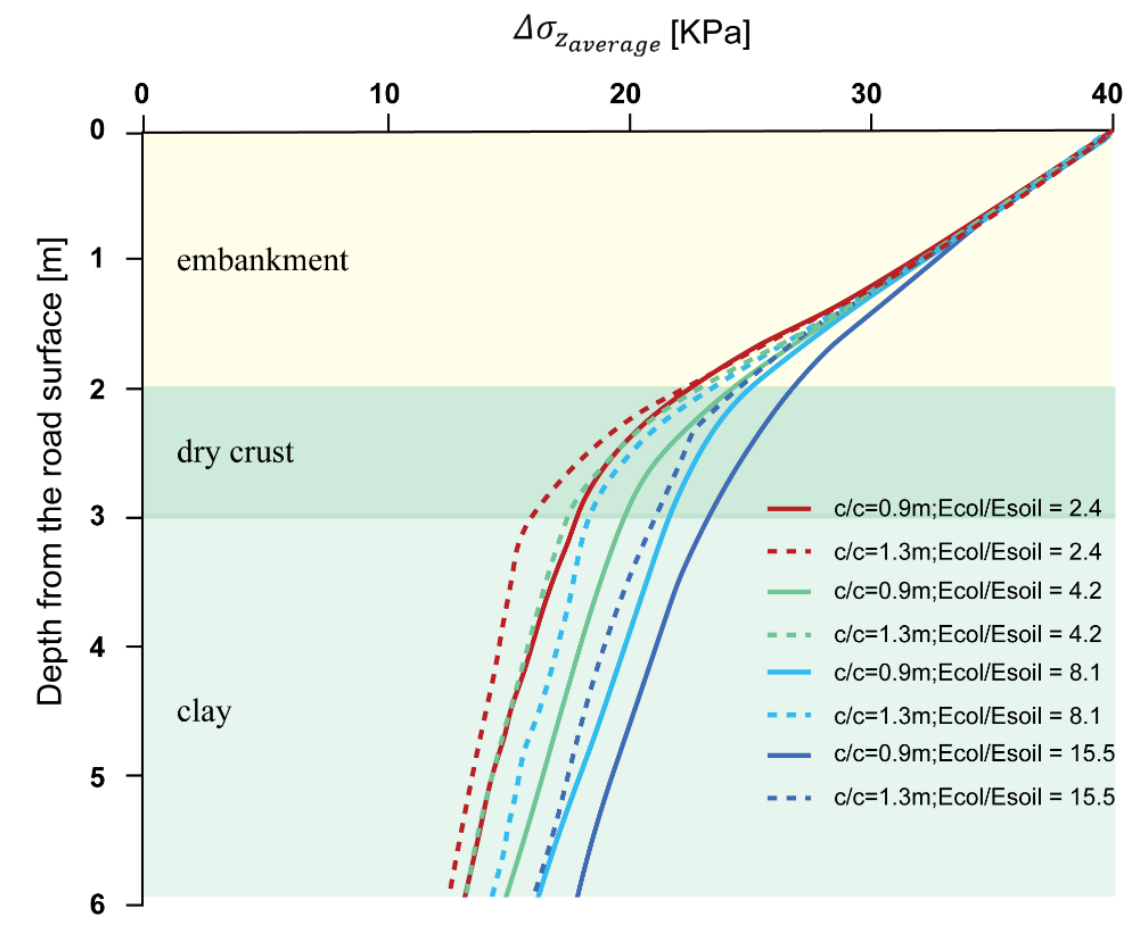

Figure 9. Average vertical stress increment for $\mathrm{c} / \mathrm{c}=0.9 \mathrm{~m}$ and $1.3 \mathrm{~m}$ with different moduli ratios of $\mathrm{E}_{\mathrm{col}} / \mathrm{E}_{\text {soil. }}$.

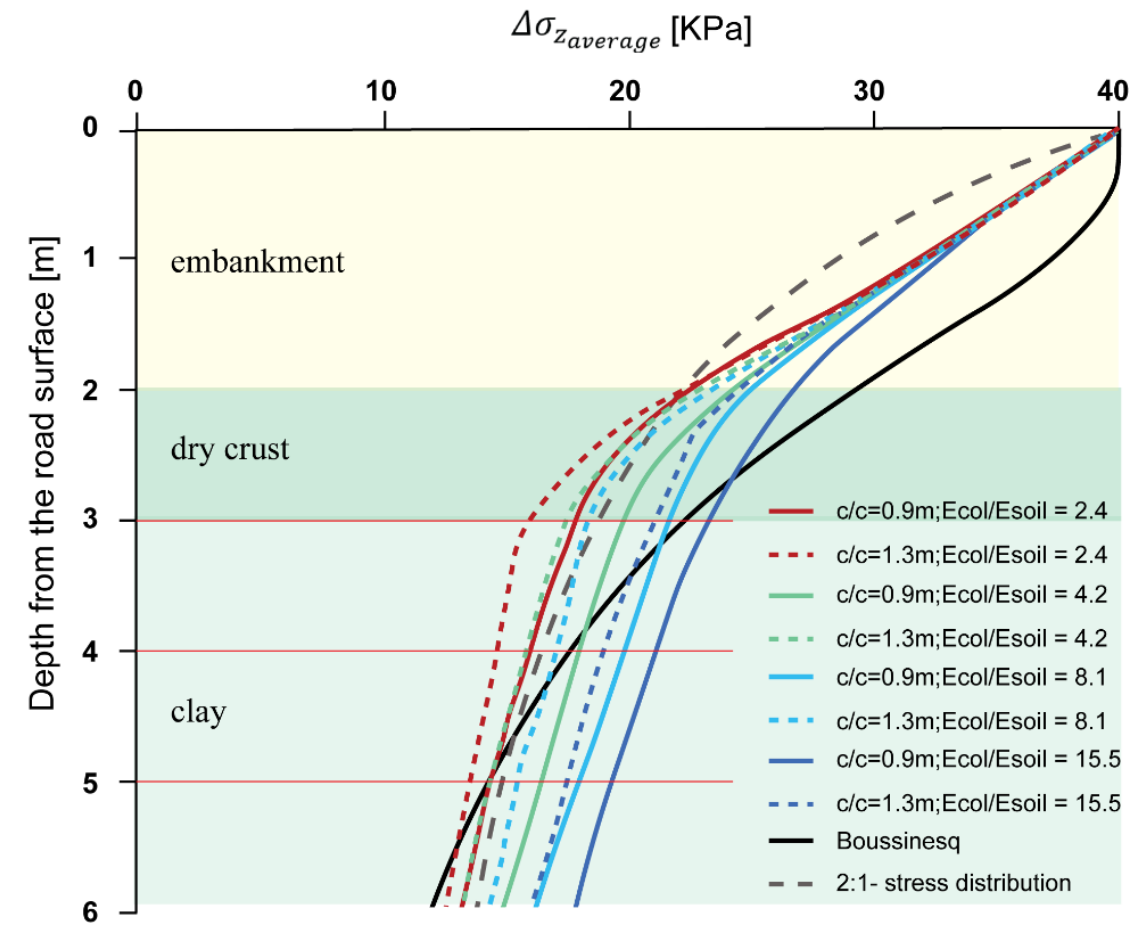

Figure 10. Average vertical stress increment and comparison to the Boussinesq and 2:1 -stress distributions. 
Table 3 presents the differences between FEM-calculated values and results from the Boussinesq stress distribution (Eq. 15) and the 2:1 stress distribution (Eq. 16) methods at the depths of 3,4 and 5 meters from the road surface.

Table 3. Difference in the total stress increment due to traffic between 3D FEM calculated results and values from the Boussinesq and the 2:1 stress distribution methods at the depths of 3,

4 and 5 meters from the road surface. All stress distributions are presented in Figure 10.

\begin{tabular}{lcc}
\hline $\begin{array}{l}\text { Depth } \\
\text { from road } \\
\text { surface }\end{array}$ & $\begin{array}{l}\text { Difference between 3D FEM and } \\
\text { Boussinesq-calculated } \Delta \sigma_{\text {zaverage }}(\text { Eq. } \\
14)\end{array}$ & $\begin{array}{l}\text { Difference between 3D FEM and 2:1- } \\
\text { stress-distribution-calculated } \Delta \sigma_{\text {zaverage }} \\
(\text { Eq. 15) }\end{array}$ \\
\hline $3 \mathrm{~m}$ & $+4 \% \ldots-28 \%$ & $+25 \% \ldots-14 \%$ \\
$4 \mathrm{~m}$ & $+18 \% \ldots-16 \%$ & $+27 \% \ldots-10 \%$ \\
$5 \mathrm{~m}$ & $+37 \% \ldots-6 \%$ & $+33 \% \ldots-9 \%$ \\
\hline
\end{tabular}

\section{Design}

Calculation results presented in Figure 9 are adopted in the new stabilisation design guidebook by FTA [7]. Both the new guidebook [7] and the previous guidebook by FTA [9] contain design examples. In one of these examples the geometry of the embankment and the soil layers are similar to those in the case of FEM analyses portrayed in this paper (Figure 2).

In stability calculations the change consists of an increase in the traffic load from the previously used $10 \mathrm{kPa}$ to $12 \mathrm{kPa}$, developed for standard cases from the traffic load in NCCI7 [8]. The settlement calculations and the verifying of arching on columns are identical in both the FTA 2010 and 2018 guidelines. The main adjustments are in the traffic loading and in verifying the compression capacity of the top of the columns.

The design example of FTA with the traffic load of $10 \mathrm{kPa}$ (Appendix 2 in [9]) gives as a result the column ratio of $\mathrm{a}=0.35\left(\mathrm{a}=\mathrm{A}_{\mathrm{col}} /\left(\mathrm{A}_{\text {soil }}+\mathrm{A}_{\text {col }}\right)\right)$ with the shear strength of $100 \mathrm{kPa}$ for columns. The same example with the new traffic load (Appendix 3 in [7]) gives also result of $\mathrm{a}=0.35$. When the shear strength of the columns is $100 \mathrm{kPa}$, this results in columns with the diameter of $600 \mathrm{~mm}$ having a column distance of $\mathrm{c} / \mathrm{c}=0.90$ $\mathrm{m}$ or with the diameter of $700 \mathrm{~mm}$ having a column distance of $1.05 \mathrm{~m}$. This means that the number of columns ends up as the same in the two cases - both with the previous traffic load of $10 \mathrm{kPa}$ and with the new one of $9+31 \mathrm{kPa}$, where $31 \mathrm{kPa}$ impacts an area of $3 \mathrm{~m} \times 5 \mathrm{~m}$. Obviously this design example is not a universal result and for instance when no dry crust exists under a moderately thin embankment, the new traffic load leads to either a smaller c/c-distance, a larger column diameter or higher column strength. Similarly, the increase in the $\mathrm{E}_{\mathrm{col}}$ to $\mathrm{E}_{\text {soil }}$ ratio results in a smaller c/c-distance, a larger diameter or higher strength of the columns.

\section{Conclusions}

Due to Eurocode recommendations there have been major increase in the intensity of the traffic loading. The 3D simulations were done to better understand the interaction 
between column and soil under a rapid traffic load. The results proved that the average vertical stress increment decreases downwards as expected, but the magnitude of the decrease differs significantly from the one determined with either the Boussinesq or the 2:1 stress distribution theory. The vertical stress increment increases when the distance between columns decreases (from $1.3 \mathrm{~m}$ to $0.9 \mathrm{~m}$ ) or when the ratio between the column and soil stiffness increases.

The aforementioned results were implemented into the updated design guidelines of Finnish Transport Agency [7] in the analytical dimensioning of deep stabilisation. On the basis of some design examples it appears that the previous design method with the traffic load of $10 \mathrm{kPa}$ leads to quite the similar number of columns as with the new traffic load of $9+31 \mathrm{kPa}$ regardless of the theoretical inadequacy in the previous traffic load consideration. If no dry crust exists under a moderately thin embankment, the new traffic loading and dimensioning leads to more conservative design with smaller c/c distance, larger columns or higher column strength.

\section{Acknowledgements}

The authors would like to acknowledge the Finnish Transport Agency, Ramboll Finland Oy and Aalto University, which collectively funded this 3D modelling project.

\section{References}

[1] A. Abed, L. Korkiala-Tanttu, J. Forsman. 3D Stress distribution modelling of deep mixing columns (Part II). Aalto University, Helsinki. 15 p, 2018. http://dx.doi.org/10.13140/RG.2.2.35120.38400

[2] A. Abed, L. Korkiala-Tanttu, J. Forsman. 3D Stress distribution modelling of deep mixing columns. Aalto University, Helsinki. 7 p, 2017.

http://dx.doi.org/10.13140/RG.2.2.31764.94084

[3] B. Broms, P. Boman. Stabilisation of soil with lime columns. Design Handbook. 92. Royal Institute of Technology, Department of Soil and Rock Mechanics, Sweden. 92 p, 1977.

[4] C. Chan. A laboratory investigation of shear wave velocity in stabilised soft soils. $\mathrm{PhD}$ Thesis. University of Sheffield. UK. 234 p, 2006. Available at: http://etheses.whiterose.ac.uk/15165/1/425591.pdf (Accessed: 17 July 2020).

[5] M. Dahlström. Dry soil mixing. In: Moseley, M. \& Kirsch, K (Eds.). Ground Improvement. Second Edition, Taylor \& Francis. New York. ISBN-13: 9780415274555, pp. 435-494, 2012.

[6] Finnish Road Administration, FINNRA. Teiden pohjarakenteiden suunnitteluperusteet "Design criteria for road base structures", TIEH 2100002 01. Finland. In Finnish. ISBN 951-726-743-6, 60 p, 2001.

[7] Finnish Transport Agency. Syvästabiloinnin suunnittelu "Deep stabilization planning” (in Finnish) Liikenneviraston ohjeita 17/2018. Liikennevirasto, Helsinki. ISBN 978-952-317-588-4, 128 p, 2018.

[8] Finnish Transport Agency. Eurokoodin soveltamisohje Geotekninen suunnittelu NCCI 7 "NCCI7 Geotechnical Design, Application guidelines for Eurocode in 
Finnish FTA's guideline" 13/2017 21.4.2017 (in Finnish). Helsinki. SBN 978-952317-387-3. 91 p, 2017.

[9] Finnish Transport Agency. Syvästabiloinnin suunnittelu "Deep stabilization planning” (in Finnish) Liikenneviraston ohjeita 11/2010. Liikennevirasto, Helsinki. ISBN 978-952-255-030-9, 57 p, 2010.

[10] J. Forsman, L. Korkiala-Tanttu, P. Piispanen. Mass Stabilisation as a Ground Improvement Method for Soft Peaty Soil. In: Topcuoglu, B. \& Turan, M. Peat. InTechOpen. pp. 107-139, 2018. http://dx.doi.org/10.5772/intechopen.74144

[11] M. Hassan. Engineering characteristics of cement stabilised soft Finnish clay - a Laboratory study, Licentiate thesis, Helsinki University of Technology, Espoo, 72 p, 2009.

[12] K. Koivisto. Katuliikenteen aiheuttaman tärinän vähentäminen syvästabiloinnin avulla "Use of Deep Stabilisation as a Countermeasure against Vehicle Generated Ground Vibration". MSc thesis. in Finnish. Helsinki University of Technology. 120 p, 2004.

[13] K. Koivisto, J. Hellberg, J. Forsman. "Finite Element Modelling of Deep Stabilisation Test Structures Used in Attenuating Railway Induced Ground Vibration at Koria, Finland" in M. Kitazume, M. Terashi, S. Tokunaga \& N. Yasuoka (eds.) Deep Mixing 2009 Okinawa Symposium, Proceedings of The International Symposium on Deep Mixing \& Admixture Stabilisation DM'09/Okinawa, Japan/19-21 May 2009. Sanwa Co., Ltd. pp. 471-476, 2009.

[14] K. Koivisto, J. Hellberg, J. Forsman. "LITES 2 - Eliminating traffic induced vibrations by means of deep stabilisation, phase 2. Report $1 \mathrm{~B}$ : Computational Analysis of the Alternative Structures", unpublished report. By Ramboll Finland Oy to Finnish Rail Administration, 2008.

[15] P. Kolisoja. Sitomattomien kerrosten kiviainesten muodonmuutosominaisuudet: esiselvitysvaiheen kuormituskokeet "Deformation properties of aggragetes of unbound layers. Loading tests of preliminary test series". Tielaitoksen selvityksiä 39/1993. in Finnish. Tielaitos. Helsinki. ISBN 951-47-7670-4, 71 p, 1993.

[16] S. Köylijärvi. Saven anisotropian ja destrukturaation vaikutuksen mallintaminen Östersundomin koepenkereellä "Effect of anisotropy and destructuration on the behaviour of Östersundom test embankment”, Master's Thesis Aalto University. (in Finnish). 96 p, 2015.

[17] F. Kulhawy, P. Mayne. Manual on estimating soil properties for foundation design. Electric Power Research Inst., Palo Alto, CA (USA); Cornell Univ., Ithaca, NY (USA). Geotechnical Engineering Group. 241 p, 1990. Available at: https://www.geoengineer.org/storage/publication/20489/publication_file/2745/EL6800.pdf (Accessed: 17 July 2020).

[18] R. Larsson, M. Mulabdic'. Shear moduli in Scandinavian clays. Shear moduli in Scandinavian clays: measurements of initial shear modulus with seismic cones: empirical correlations for the initial shear modulus in clay. Swedish Geotechnical Institute. 40. ISSN 0348-0755, 127 p, 1991. Available at: https://www.divaportal.org/smash/get/diva2:1299970/FULLTEXT01.pdf (Accessed: 17 July 2020).

[19] M. Löfman. Perniön saven parametrien luotettavuuden ja saven eri ominaisuuksien välisten korrelaatioiden arviointi "Estimation of the reliability of 
Perniö clay parameters and correlations between clay properties", Master's thesis Aalto University. In Finnish. 121 p, 2016.

[20] J. Mäenpää. Seismisen CPTU-mittauksen käyttö leikkausaallon nopeuden määrittämiseen "Determining shear wave velocity by seismic CPTU". Master's thesis, Technical University of Tampere. In Finnish. 96 p, 2016.

[21] M. Navin. Stability of embankments founded on soft soil improved with deepmixing-method columns. PhD Thesis. Virginia Polytechnical Institute. 188 p, 2005. Available at: https://vtechworks.lib.vt.edu/bitstream/handle/10919/28654/dissertation_revised.p df? sequence $=2 \&$ isAllowed $=y$ (Accessed: 17 July 2020).

[22] PLAXIS 3D. Plaxis bv. Delft. The Netherlands, 2016.

[23] H. Poulos, E. Davis. Elastic solutions for soil and rock mechanics. John Wiley \& Sons. New York. 411 p, 1974.

[24] B. Ringesten. Dry crust - its formation and geotechnical properties. $\mathrm{PhD}$ thesis. Chalmers University of Technology. Göteborg. Sweden. ISSN 0346-718X, 191 p, 1990.

[25] N. Ronkainen. Suomen maalajien ominaisuuksia Suomen Ympäristö "Characteristics of Finnish soils" 2/2012. In Finnish. ISBN 978-952-11-3975-8. 62 p., 2012.

[26] P. Robertson. Seismic CPT (SCPT) [PowerPoint presentation]. Second International Conference on Deep Foundations $\left(2^{\circ}\right.$ C.F.P.B): Field Testing and Construction Aspects of Deep Foundations. Campo Ferial Fexpocruz, Santa Cruz, Bolivia, 12-15 May, 2015. Available at: http://cfpbolivia.com/2015/Robertson/Seismic-cpt(scpt)-peter-robertson.pdf (Accessed: 28 February 2019).

[27] Swedish Road Administration (Trafikverket). Trafikverkets tekniska krav för geokonstruktioner TK Geol3 (No. TRV 2014/13914). Swedish Road Administration, Sweden. In Swedish. 105 p, 2014. Available at: http://www.th.tkgbg.se/Portals/0/STARTFLIKEN/Checklistor\%20och\%20mallar/2 _\%20Projektering\%20dokument/TK\%20Geo\%2013\%20Trafikverkets\%20teknisk a\%20krav\%20f\%C3\%B6r\%20geokonstruktioner_2015-12.pdf (Accessed: 28 February 2019).

[28] M. Timoney. Strength verification methods for stabilised soil-cement columns: a laboratory investigation of PORT and PIRT. PhD Thesis. National University of Ireland, Gal-way. 328 p, 2015. Available at: https://aran.library.nuigalway.ie/handle/10379/5023 (Accessed: 17 July 2020).

[29] J. Toikka, P. Virtala. Axle weight study 2013-2014. Research reports of the Finnish Transport Agency 67/2015. Finnish Transport Agency, Helsinki. ISBN 978-952317-179-4, 74 p, 2015.

[30] M. Topolnicki. In-situ soil mixing. In: M. Moseley, K. Kirsch (Eds.) Ground Improvement. Second Edition, CRC Press. 488 p, 2004.

[31] J. Vinter. The effect of the sub-ballast layer material to the performance of groundsupported railway embankment. Master's thesis. In Finnish. Aalto University Espoo. 96 p, 2015.

[32] U. Vogler. Numerical modelling of deep mixing with volume averaging technique. PhD Thesis. The University of Strathclyde. Strathclyde. UK. 233 p, 2008. 
[33] C. Wroth. In-situ measurements on initial stresses and deformations characteristics. Proceedings Conference in-situ Measurements of Soil Properties. Raleigh. North Carolina. Vol. 2, pp. 181-230, 1975.

\author{
Ayman A. Abed \\ Chalmers University of Technology \\ Department of Architecture and Civil Engineering \\ Sweden \\ Formerly: \\ Aalto University \\ Department of Civil Engineering \\ P.O.Box 12100, FI-00076 Aalto \\ Finland \\ ayman.abed@chalmers.se \\ Leena Korkiala-Tanttu \\ Aalto University \\ Department of Civil Engineering \\ P.O.Box 12100, FI-00076 Aalto \\ Finland \\ leena.korkiala-tanttu@aalto.fi \\ Juha Forsman, Kirsi Koivisto \\ Ramboll Finland Oy \\ Espoo \\ Finland \\ juha.forsman@ramboll.fi, kirsi.koivisto@ramboll.fi
}

